\title{
ANALISIS PENGARUH 7 DAY RATE REPO, INFLASI, NILAI TUKAR, DAN PDB TERHADAP INDEKS HARGA SAHAM SEKTOR PROPERTI (STUDI EMPIRIS DI BURSA EFEK INDONESIA)
}

\author{
RAHMA WIYANTI \\ Prodi Akuntansi S1 Universitas Pamulang \\ *Email: wiyan_zal@yahoo.com
}

\begin{abstract}
Since the introduction of the new 7-day Repo rate formula in 2016, it will be a signal for investors, especially the property sector to invest in capital markets. Enforcement is encouraging the property sector to grow because it is expected the new interest rate formula with a value lower than before can attract consumers to invest in property. With the widespread demand for property pushed the performance of property entrepreneurs to become better in the financial sector. The development of property performance is seen from the Stock Price Index in the property sector. Researchers test whether the formula along with other macro variables such as Inflation, Exchange Rate and GDP can affect the valuation of investors in investment in the capital market, especially in the property sector. Analysis test that has been done by using statistical method of Multiple Linear Regression Test, Correlation Coefficient Test, Determination Coefficient Test, F Test and T Test resulted in 7 Days Rate Ratio and exchange rate significantly affect Stock Price Index in property sector while Inflation and GDP did not influence Stock Price Index of property sector, but simultaneously produce variable 7 Day Rate Repo, Inflation, exchange rate and GDP effect on Stock Price Index in property sector.
\end{abstract}

\section{ABSTRAK}

Sejak diberlakukannya formula baru 7 Days Rate Repo pada tahun 2016 maka menjadi sinyal bagi para investor khususnya sektor properti untuk berinvestasi di pasar modal. Pemberlakuan tersebut mendorong sektor properti untuk semakin tumbuh karena diharapkan formula suku bunga yang baru dengan nilai yang lebih rendah dari sebelumnya dapat menarik minat konsumen melakukan investasi dalam bentuk properti.Dengan semakin maraknya permintaan terhadap properti mendorong kinerja pengusaha properti untuk lebih baik dalam sektor finansial.Perkembangan kinerja properti dilihat dari Indeks Harga Saham di sektor Properti. Peneliti melakukan pengujian apakah formula tersebut beserta variable makro lain yaitu Inflasi, Nilai Tukar dan PDB dapat mempengaruhi penilaian investor dalam menanamkan dananya di pasar modal khususnya disektor properti. Dengan pengujian yang telah dilakukan menggunakan metode statistik Multiple Linear Regression Test, Correlation Coefficient Test, Coefficient of Determination Test, F Test and T Test maka dihasilkan bahwa 7 Days Rate Repo dan nilai tukar berpengaruh signifikan terhadap Indeks Harga Saham di sektor properti sedangkan Inflasi dan GDP tidak berpengaruh terhadap Indeks Harga Saham sektor Properti, akan tetapi secara simultan dihasilkan bahwa variable 7 Day Rate Repo, Inflasi, Nila Tukar dan GDP berpengaruh terhadap Indeks Harga Saham di sektor property

Keywords: 7 Day Rate Repo, Inflation, Exchange Rate, GDP, Stock Price Index in Property 


\section{PENDAHULUAN}

Sektor Properti sangat menarik untuk dibahas mengingat semakin bartambahnya jumlah penduduk di Indonesia tiap tahunnya. Demografi Indonesia memiliki populasi yang besar, lebih dari 250 juta pada tahun 2015 dengan populasi usia muda berumur 30 tahun (Indonesia Investama, 2015). Hal tersebut dapat memprediksi bahwa akan maraknya orang Indonesia akan membeli properti pertama mereka dalam jangka waktu menengah. Pasar Properti naik tajam dapat dipengaruhi berbagai faktor, diantaranya rendahnya tingkat suku bunga Bank Sentral antara Pebruari 2012 sampai pertengahan 2013, yaitu suku bunga acuannya (BI rate) pada 5,75\%. Suku bunga terendah pada saat itu se-Asia Tenggara.

Di pertengahan kedua tahun 2013, Bank Indonesia semakin khawatir mengenai berkembang pesatnya properti karena perekonomian umum sedang melambat namun sektor properti naik sangat tinggi di pertengahan pertama tahun 2013 (kehati-hatian telah menjadi karakteristik pihak berwenang Bank Indonesia setelah Krisis Finansial Asia). Bank Indonesia (BI) mengatakan bahwa pihak BI sudah mendeteksi pembelian spekulatif dan karenanya mengimplementasikan kebijakan pengetatan moneter. Meskipun kecil kemungkinan bahwa pesatnya penawaran properti tersebut akan ada titiknya (karena permintaaan domestik untuk properti tetap besar dan, sementara harga properti - meskipun telah meningkat cepat - masih tergolong rendah dibanding kota-kota lain di Asia), pembelian spekulatif memang bertumbuh (Setianto, 2016). Beberapa atau hampir sebagian besar pengembang properti di Indonesia menjual unit properti baru walaupun kontruksi belum dilaksanakan (baik rumah tapak ataupun apartemen).Ditambah lagi beberapa investor yang melakukan pembelian beberapa unit pada tahap pembangunan dengan harga yang murah dan kemudian mengalihkan unit yang telah dibeli tersebut dengan menjualnya kembali dengan harga yang lebih tinggi.

Di pertengahan kedua tahun 2013, Bank Indonesia mengetatkan kebijakannya.BI menaikkan persyaratan uang muka minimum (Loan to value) dan memotong pinjaman hipotek untuk kepemilikan rumah kedua (untuk mencegah peningkatan berlebihan dari pinjaman untuk hunian). Bank-bank juga dilarang memberikan pinjaman untuk propertiproperti yang masih dalam proses pembangunan (untuk para pembeli hunian kedua atau lebih). Persyaratan uang muka yang lebih tinggi (atau rasio loan-to-value yang lebih rendah) diaplikasikan untuk properti-properti berukuran lebih dari 70 meter persegi, dan karenanya secara spesifik ditujukan untuk pasar menengah ke atas.

Perubahan penting lainnya termasuk tingkat suku bunga Indonesia. Setelah sentuh titik rendah dalam sejarah pada 5,75\% dari Februari 2012, Bank Indonesia secara bertahap, namun agresif, menaikkan BI rate antara Juni 2013 sampai November 2013 menjadi 7,50\%. Periode yang lebih ketat ini diimplementasikan dalam rangka melawan inflasi tinggi (yang terjadi setelah Pemerintah Indonesia menaikkan harga bahan bakar bersubsidi), untuk melawan defisit transaksi berjalan yang lebar, dan mengatasi ketidakjelasan dunia internasional (karena pengetatan kebijakan moneter Amerika Serikat, terjadi capital outflows besar-besaran dari Indonesia dan menyebabkan pelemahan tajam nilai tukar rupiah sejak pertengahan 2013).

Pemilihan legislatif dan presiden pada tahun 2014 mempengaruhi dari sisi politik sehingga berdampak pada ketidakjelasan perekonomian. Pada saat pemilihan ini para pengembang menunda kontruksi terhadap perumahan yang merupakan dampak dari menurunnya pencairan pinjaman perbankan dan BI rate yang lebih tinggi. Bersama-sama, faktor-faktor ini menyebabkan penurunan pasar properti Indonesia. Contohnya, Indeks Harga Properti Hunian dari Bank Indonesia menurun 6,3\% di 2014, turun dari tingkat pertumbuhan tahunan sebesar $11,5 \%$ pada setahun sebelumnya (terlebih lagi inflasi Indonesia naik $8,4 \%$ di 2014, karenanya melebihi kecepatan pertumbuhan indeks harga properti). Penurunan terbesar untuk pertumbuhan properti dirasakan di wilayah Jakarta Bogor Depok Tangerang \& Bekasi (Jabodetabek).Ini juga merupakan akibat dari pasar properti Jakarta (dan juga pasar-pasar lainnya di kota-kota besar di Jawa seperti Surabaya dan Bandung) telah menjadi agak jenuh 
karena pembangunan properti besar-besaran di tahun-tahun sebelumnya.Pulau-pulau lain, seperti Sumatra, Sulawesi dan Kalimantan, kini dipandang sebagai pasar berpotensi besar untuk pembangunan properti (perkotaan) karena saat ini masih belum banyak dikembangkan.Beberapa faktor yang telah diungkapkan diatas membuat sektor properti mati suri sampai pada tahun 2016. Ditambah lagi, pertumbuhan ekonomi yang semakin menurun dari tahun 2013 sampai dengan 2016 membuat investasi disektor properti semakin tertekan.

Pada tanggal 19 Agustus 2016 Bank Indonesia (BI) mengumumkan formula baru suku bunga acuan perbankan, yakni BI 7-Day Reverse Repo Rate, yang akan menggantikan formula sebelumnya yakni BI Rate. Ini adalah kali pertama BI sebagai bank sentral melakukan perubahan kebijakan yang tampak radikal, dan itu tentu membuat bingung para investor.Saham-saham khususnya perbankan langsung berjatuhan, karena investor menjadi unsure soal bagaimana dampak dari penetapan formula baru ini terhadap kinerja perusahaan.Perlu untuk diketahui bahwa, pergerakan saham-saham yang berada dalam sektor perbankan mirip dengan pergerakan IHSG.Hal ini dikarenakan saham-saham perbankan sebagian besar berkapitalisasi besar sehingga dapat menyetir pergerakan IHSG.

Setelah mengalami kekhawatiran dari beberapa tahun terakhir persisnya diawal Juni 2013 dimana pasar properti mengalami penurunan, pasar properti untuk kalangan menengah keatas kembali bergembira di berlakukannya suku bunga acuan yang baru. Para pengembang sudah mulai melakukan aksi investasi pada proyek-proyek properti. Ferry Salanto (2017), Senior Assosiciate Director Research Colliers Directors International melihat tren industri properti secara keseluruhan memang sedang bergerak naik. Ditambah lagi secara makro Bank Indonesia sudah percaya diri menurunkan suku bunga." Momentum ini akan ditangkap pengembang dan pasar untuk bergerak naik (Hutauruk, Kontan (2017: 20). Oleh karena banyak para pengusaha melirik pada proyek ini diantaranya:

\begin{tabular}{lll}
\hline Pengembang & Nama Proyek & Harga \\
\hline PT Intiland Development & City57 dan Sky 57 & Rp. 2,8 M - Rp. 9 M \\
PT Adhi Persada Properti & The Padmaya & Rp. 3M - Rp. 20 M \\
PT Patrajasa & Patra Oil Village & Rp. 40 Juta/m2 \\
PT PP Properti & Grand Samaya & Rp. 1,2M \\
PT Sinar Mas Land & Aerium & Rp. 2,5M \\
\hline
\end{tabular}

Sumber : wawancara dan riset Kontan (2017:20)

Para pengamat ekonomi memberikan opini untuk menanggapi perubahan suku bunga acuan 7 Days Rate Repo akan memberikan dampak positif. Tidak hanya dengan penurunan suku bunga saja ternyata Bank Indonesia (BI) melakukan stimulus baru dalam pemberian kredit loan to value (LTV) kredit pemilikan rumah (KPR) dan kredit kendaraan bermotor. Kaitan suku bunga terhadap harga saham dikemukakan pula oleh Boedie et al (1995) yang menyatakan bahwa perubahan harga saham dipengaruhi oleh beberapa faktor, salah satunya adalah suku bunga. Hal tersebut didukung pula dengan penelitian yang dilakukan oleh Utami dan Rahayu (2003) yang menemukan secara empiris pengaruh suku bunga terhadap harga saham selama masa krisis di Indonesia.

Penelitian mengenai hubungan antara inflasi dengan harga saham seperti yang dilakukan oleh Widjojo (dalam Almilia, 2003) menyatakan bahwa makin tinggi inflasi akan semakin menurunkan tingkat profitabilitas perusahaan. Turunnya profit perusahaan adalah informasi yang buruk bagi para trader di bursa saham dan dapat mengakibatkan turunnya harga saham perusahaan tersebut. Sebaliknya Sangkyun Park (1997) yang meneliti kaitan antara Variabel makro, Indeks harga Konsumen, GDP, tingkat Inflasi, dan suku bunga terhadap harga saham menemukan bahwa hanya GDP yang berpengaruh positif terhadap harga saham sedangkan variabel lainnya tidak berpengaruh. 
Penelitian hubungan pertumbuhan GDP terhadap harga saham yang telah dilakukan oleh Sangkyun Park (1997) diatas tadi menemukan adanya pengaruh positif pertumbuhan GDP terhadap harga saham, sedangkan Fama dan French (1981) yang meneliti kaitan antara return saham dengan tingkat suku bunga, inflasi dan pertumbuhan ekonomi, hanya menemukan pengaruh negatif inflasi terhadap harga saham dan tidak menemukan pengaruh suku bunga dan pertumbuhan ekonomi terhadap harga saham. Tandelilin (1997) juga memperkuat pernyataan diatas dengan menemukan pertumbuhan GDP tidak berpengaruh terhadap indeks saham.

Thobarry (2009) melakukan penelitian sebelumnya mengenai pengaruh nilai tukar, suku bunga, laju inflasi dan pertumbuhan GDP terhadap harga saham di bursa pada tahun 2000-2008 dimana nilai tukar dollar terhadap rupiah, suku bunga, inflasi dan pertumbuhan GDP secara bersama-sama berpengaruh terhadap indeks harga saham sektor properti, sedangkan secara parsial nilai tukar dollar terhadap rupiah berpengaruh positif signifikan terhadap indeks harga saham sektor properti sedangkan nilai inflasi berpengaruh negative terhadap indeks saham sektor properti. Peneitian kali ini ingin menguji apakah variable tersebut tetap mempengaruhi pada periode penelitian, dimana pada periode penelitian suku bunga acuan mengalami perbedaan formula dimana BI rate menjadi 7 Day Rate Repo.

Seperti yang telah diuraikan diatas bahwa harga saham berfluktuatif dipengaruhi dari bebarapa faktor dengan dibuktikannya oleh penelitian sebelumnya. Sektor properti banyak dipengaruhi oleh beberapa kondisi ekonomi apabila terjadi kenaikan/penurunan. Diberlakukannya formula baru terhadap suku bungaBI Rate menjadi 7 Day Rate Repo, inflasi yang berdampak pada bertambahnya permintaan terhadap properti, serta laju pertumbuhandapat mempengaruhi permintaan terhadap properti. Maka dengan latar belakang yang telah diungkapkan maka penelitian ini akan menganalisis pengaruh 7 Day Rate Repo, laju inflasi, nilai tukar, dan PDP terhadap Indeks Harga Saham di sektor Properti.

\section{LANDASAN TEORI}

\section{Indeks Harga Saham}

Kejadian historis dapat disajikan dalam suatu sistem tertentu sehingga dapat menghasilkan informasi yang lebih sederhana dan dapat dengan mudah dipahami para investor. Informasi tersebut digambarkan dalam bentuk angka atau istilah-istilah tertentu, berdasarkan hal inilah para investor dapat melakukan prediksi dimasa yang akan datang. Dengan informasi historis juga maka terlihat pergerakan harga saham dimasa lalu yaitu indeks harga saham yang memberikan deskripsi harga-harga saham pada saat tertentu dan dalam periode tertentu pula. Indeks harga saham tersebut merupakan catatan terhadap perubahanperubahan maupuun pergerakan harga saham sejak mulai pertama kali beredar sampai pada suatu saat tertentu. Indeks Harga Saham dijadikan sebagai landasan analisis statistik atas pasar.Keadaan ekonomi tersebut meliputi mikro dan makro ekonomi dimana perubahannya dapat dilihat dengan perubahan indeks harga saham.Adapan faktor makro yang mempengrauhi perubahan adalah nilai tukar, suku bunga, tingkat inflasi (Thobarry, 2009).

\section{Day Rate Repo}

Investor yang melakukan perdagangan saham di suatu negara harus memperhatikan bagaimana keadaan ekonomi baik itu keadaan moneter ataupun pergerakan makro ekonomi seperti adanya suku bunga, inflasi, nilai tukar dan PDB.Berdasarkan beberapa penelitian sebelumnya terdapat pengaruh terhadap harga saham, baik di sektor perbankan sakalipun. Bank Sentral berkewajiban melaksakan kebijakan moneter, dengan mengontrol stabilitas perekonomian agar tidak mengalami inflasi maupun deflasi (Suparmoko, 2006;136).Sebelum tanggal 19 Agustus 2016 Bank Indonesia memiliki BI Rate sebagai suku bunga acuan. Hingga pada tanggal 19 Agustus 2016 formula tersebut dirubah menjadi 7 Day Rate Repo sebagai suku bunga acuan Bank Indoensia. Suku bunga acuan Bank Indonesia tergolong rendah. 
Setelah menurunkan tingkat suku bunga beberapa kali, pada tahun 2013 BI rate di level 7.5 $\%$, dan saat ini BI rate di level $6.5 \%$. Ditambah lagi dengan adanya formula baru menjadi 7 Day Rate Repo sampai akhir tahun 2017 berada di level 4,25\%. Dengan demikian, maka tingkat suku bunga KPR juga semakin rendah. Selain itu, beberapa investor mulai merasa bahwa bunga deposito mengecil, sehingga mereka mulai melirik investasi lainnya seperti investasi properti dan pasar modal. BI yang mempunyai otoritas terhadap fluktuasi nilai rupiah, kontrol inflasi dan kebijakan-kebijakan lainnya. Bank Indonesia punya peran penting dalam membuat kebijakan-kebijakan terutama penentuan suku bunga. BI melakukan penguatan operasi moneter dengan memperkenalkan suku bunga acuan baru yaitu BI 7 Days Rate Repo (7DRR). BI tidak mengubah tingkat suku bunga kebijakan melainkan mengubah tenor suku bunga kebijakan BI rate yang bertenor 360 hari menjadi tenor 7 hari. Perubahan tersebut ditunjukkan untuk memperkuat efektivitas kebijakan moneter, sehingga setiap ada perubahan tingkat bunga kebijakan, baik kenaikan maupun penurunan, dampaknya terhadap suku bunga pasar uang dan perbankan, baik deposito ataupun kredit akan cepat membaik. Dengan jangka waktu yang lebih pendek, maka BI 7 DRR memiliki suku bunga/rate yang lebih rendah daripada $B I$ rate.Sejak diberlakukannya 7DRR, Bank Indonesia berharap kebijakannya tersebut dapat mengontrol dengan efektif tigkat suku bunga. Yang tentunya berdampak pada penyaluran kredit dari perbankan ke masyarakat menjadi lebih lancar dan resiko kredit macet karena perubahan suku bunga yang lebih kecil. Pertumbuhan ekonomi yang diinginkan tercapai.Kebijakan ini memiliki dampak yang besar terhadap perekonomian secara umum. Dengan memahami peran 7 DRR dalam perekonomian nasional, maka kita akan bisa mengambil keputusan dan piihan yang tepat terkait dengan perubahan-perubahan yang terjadi dalam sistem keuangan.

\section{Nilai Tukar}

Nilai tukar adalah sebagai perbandingan antara harga mata uang suatu negara dengan harga mata uang negara lain (Musdholifah dan Tony (2007). Nilai tukar antar mata uang disebut juga sebagai nilai kurs, nilai kurs merupakan harga satu satuan mata uang asing dalan suatu negari. Atau dengan kata lain apabila ditukarkan dengan satu mata uang asing lainnya. Dalam kurs terdapat istilah kurs jual dan kurs beli. Kurs jual dan kurs beli tersebut digunakan oleh perusahaan money changers untuk memperoleh keuntungan dari penukaran mata uang asing. Kurs jual adalah kurs yang berlaku saat kita ingin menjual rupiah kepada money changer atau akan menukarkan rupiah dengan mata uang asing. Kurs beli adalah kurs yang berlaku saat kita ingin menukar kan mata uang asing dengan mata uang rupiah (kita ingin membeli rupiah). Perubahan nilai mata uang akan mempengaruhi nilai tukar. Pada umumnya nilai mata uang akan cendrung meningkat apabila permintaan terhadap mata uang " $x$ " tersebut lebih besar dibandingkan dengan persediaan yang ada, serta nilai mata uang akan cendrung menurun apabila permintaan terhadap mata uang tersebut lebih kecil dari persediaan yang ada. Perubahan dalam permintaan dan penawaran terhadap sesuatu mata uang yang selanjutnya mengakibatkan perubahan dalam nilai tukar. Faktor-faktor yang dapat mempengaruhi nilai tukar diantaranya adalah perubahan cita rasa masyarakat, perubahan harga barang ekspor dan impor, kenaikan harga umum (inflasi), perubahan suku bunga dan tingkat pengembalian investasi dan pertumbuhan ekonomi (Sukirno, 2012;402)

\section{Inflasi}

Menurut Bodie dan Marcus (2001:331), inflasi merupakan suatu nilai dimana tingkat harga barang dan jasa secara umum mengalami kenaikan. Inflasi adalah salah satu peristiwa moneter yang menunjukkan suatu kecenderungan akan naiknya harga-harga barang secara umum, yang berarti terjadinya penurunan nilai uang. Penyebab utama dan satu-satunya yang memungkinkan gejala ini muncul menurut Teori Kuantitas mengenai uang pada mazhab 
klasik adalah terjadinya kelebihan uang yang beredar sebagai akibat penambahan jumlah uang di masyarakat. Menurut Keynes dalam The General Theory of Employment, Interest and Money, bahwa inflasi disebabkan oleh gap antara kemampuan ekonomi masyarakat terhadap keinginan-keinginannya terhadap barang-barang (Shapiro, 2002). Yang dimaksud dengan gap disini adalah permintaan masyarakat terhadap barang-barang lebih besar daripada jumlah yang tersedia sehingga terjadi kenaikan harga, yang kemudian dikenal dengan istilah inflationary gap.Inflasi pundapat timbul bila jumlah uang atau uang deposito dalam peredaran banyak, dibandingkan dengan jumlah barang-barang atau jasa yang ditawarkan atau bila karena hilangnya kepercayaan terhadap mata uang nasional, terdapat gejala yang meluas untuk menukar dengan barang-barang.Penurunan daya beli baik individu maupun suatu entitas terkait dengan inflasi.Hampir semua negara pernah mengalami inflasi, karena didalam perekonomian suatu negara ada saja suatu faktor yang dapat menyebabkan tingkat harga melonjak serentak, danada faktor tertentu yang dapat menyebabkan tingkat harga naik perlahan.Maka situasi yang membuat naiknya tingkat harga disebut gejolak inflasi.

\section{Produk Domistik Bruto (PDB)}

Produk Domestik Bruto diartikan sebagai jumlah produksi barang dan jasa yang dihasilkan oleh unit-unit produksi pada suatu daerah di saat tertentu (Mankiw, 2006;18). Nilai keseluruhan semua barang dan jasa yang diproduksi di dalam wilayah tersebut dalam jangka waktu tertentu.PDB berbeda dari produk nasional bruto karena memasukkan pendapatan faktor produksi dari luar negeri yang bekerja di negara tersebut. Sedangkan PDB yang menghitung total produksi dari suatu negara tanpa memperhitungkan apakah produksi itu dilakukan dengan memakai faktor produksi. Alat pengukur dari pertumbuhan ekonomi adalah PDB, PDB perkapita dan Pendapatan per jam Kerja.Pengukuran pendapatan perkapita di Indonesia menggunakan Produk Domestik Bruto/PDB (Gross Domestic Product/GDP).PDB Indonesia adalah nilai barang dan jasa yang dilakukan oleh seluruh faktor produksi di Indonesia baik yang dimiliki oleh orang Indonesia sendiri maupun oleh orang asing.Sedangkan angka pendapatan perkapita dihasilkan melalui membagi PDB Indonesia pada suatu periode dengan jumlah penduduk Indonesia. Sangkyun Park (1997) yang meneliti kaitan antara variabel makro, harga konsumen, GDP, tingkat inflasi, suku bunga dan return saham menemukan adanya pengaruh positif antara pertumbuhan GDP dan return saham. Dengan meningkatnya kinerja ekonomi yang dicerminkan oleh pertumbuhan GDP, investor cenderung akan lebih banyak berinvestasi di pasar modal. Dengan meningkatnya pertumbuhan GDP juga dapat mengakibatkan naiknya daya beli masyarakat yang imbasnya bisa saja dirasakan oleh pasar saham.

\section{Hipotesis}

H1: Diduga terdapat pengaruh 7 Days Rate Repo terhadap Indeks Harga Saham di sektor Properti

H2: Diduga terdapat pengaruh nilai tukar terhadap Indeks Harga Saham di Sektor Properti

H3: Diduga terdapat pengaruh inflasi terhadap Indeks Harga Saham di Sektor Properti

H4: Diduga terdapat pengaruh PDB terhadap Indeks Harga Saham di Sektor Properti

\section{METODOLOGI PENELITIAN}

Lokasi yang dilakukan pada penelitian ini pada perusahaan properti yang terdaftar di Bursa Efek Indonesia yang dapat diperoleh melalui situs www.idx.co.id. Sifat dari penelitian ini adalah deskriptif kuantitatif, yakni penelitian yang memberikan gambaran atau deskripsi suatu data yang dilakukan dalam hal untuk mengetahui adanya hubungan antara variabel bebas dengan variabel terikat. Dimana dalam penelitian ini yang menjadi variabel independen (X) ialah 7 Day Rate Repo, Nilai Tukar, Inflasi, Produk Domestik Bruto dan variabel 
dependen (Y) Indeks Harga Saham di Sektor Properti. Jenis pengumpulan data dalam penelitian ini adalah dengan mendokumentasikan yaitu mencatat data bulanan yang tercantum pada www.mediainvestasi.comuntuk data indeks harga saham properti bulanan. Untuk data kurs, suku bunga dan Inflasi bulanan diperoleh dari situs resmi Bank Indonesia (www.bi.go.id), serta BPS (Badan Pusat Statistik) untuk data pertumbuhan PDB digunakan data 3 bulanan karena Bank Indonesia dan BPS hanya mengeluarkan laporan PDB setiap 3 bulan. Populasi Penelitian ini semua perusahaan properti yang listing di Bursa Efek Indonesia yang terdiri dari 65 emiten dan 17 jumlah bulan penelitian. Sampel yang digunakan adalah 65 emiten yang listing di Bursa Efek Indonesia di sektor property dan periode peneltian yang dilakukan sejak berlakuya 7 Days Rate Repo tanggal 19 Agustus 2016. Jenis data yang digunakan dalam penelitian ini adalah data sekunder.

\section{Metode Analisis Data}

Teknik analisis yang digunakan dalam penelitian ini adalah analisis data kuantitatif, untuk memperkirakan secara kuantitatif pengaruh dari beberapa variabel Independen secara bersama-sama maupun secara sendiri-sendiri terhadap variable dependen.Hubungan fungsionalantara satu variabel dependen dengan variabel independen dapat dilakukan dengan regresi berganda. Metode analisis statistic yang perhitungannya dilakukan dengan menggunakan SPSS versi 24,0, sehingga pengujian yang dilakukan sebagai berikut:

\section{HASIL PENELITIAN DAN PEMBAHASAN}

Penelitian ini terlebih dahulu melalui uji asumsi klasik yang semuanya memenuhi syarat untuk dilanjutkan ke pengujian Regresi. Dari hasil pengujian didapatkan model persamaan regresi sebagai berikut :

$$
\mathrm{Y}=850,80-2355,29 \mathrm{X} 1+22,22 \mathrm{X} 2+0,027 \mathrm{X} 3-92,995 \mathrm{X} 4+€
$$

1.Konstanta 850,80 menunjukkan bahwa jika 7 Day Rate Repo (X1), inflasi (X2), nilai tukar (X3), PDB (X4) nilainya 0, maka indeks harga saham sektor properti (Y) nilainya konstan sebesar Rp. 850,80.

2.Koefisien regresi variabel 7 Days Rate Repo sebesar - 2355,299 menunjukkan bahwa jika variabel independen lain nilainya tetap dan 7 Days Rate Repo mengalami kenaikan 1\%, maka harga saham properti (Y)akan mengalami penurunan sebesar Rp. 2.355,29. Koefisen negatif artinya ada hubungan negatif antara 7 Day Rate Repo dengan Indeks Harga Saham Properti, semakin rendah 7 Day Rate Repomaka semakin tinggi Indeks Harga Saham sektor Properti, begitu juga sebaliknya semakin tinggi 7 Day Rate Repo maka semakin rendah Indeks Harga Saham di sektor Properti.

3.Koefisien regresi variabel inflasi sebesar 22,224 menunjukkan bahwa variabel independen mengalami kenaikan 1\%, maka indeks harga saham sektor properti akan mengalami peningkatan sebesar Rp. 22,224. Koefisien positif artinya ada hubungan positif antara inflasi dengan indeks harga saham sektor properti, semakin rendah inflasi maka semakin rendah indeks harga saham properti

4.Koefisien regresi variabel nilai tukar sebesar 0,027, menunjukkan bahwa variabel independen mengalami kenaikan $1 \%$, maka indeks harga saham properti akan mengalami peningkatan sebesar Rp. 0,027. Koefisisen positif artinya ada hubungan positif antara nilai tukar dengan indeks harga saham sektor properti, semakin tinggi nilai tukar rupiah terhadap dollar maka semakin tinggi indeks harga saham disektor properti.

5.Koefisien regresi variabel PDB (Produk Domestik Bruto) sebesar -92,995, menunujukkan bahwa variabel independen mengalami kenaikan $1 \%$, maka indeks harga saham properti akan mengalami penurunan sebasar Rp 92,995. Koefisien negatif artinya ada hubungan negatif 
antara PDB dengan Indeks Harga Saham sektor properti maka, semakin tinggi PDB suatu negara maka semakin rendah Indeks Harga Saham disektor properti.

\section{Hasil Uji Koefisien Determinasi}

Hasil Uji Korelasi Determinasi $\left(\mathbf{R}^{2}\right)$

\begin{tabular}{ccccc}
\hline \multicolumn{4}{c}{ Model Summary $^{\mathbf{b}}$} \\
\hline Model & $\mathrm{R}$ & R Square & Adjusted R Square & Std. Error of the Estimate \\
1 & $.710^{\mathrm{a}}$ & 0.504 & 0.363 & 29.5428052 \\
\hline Constant), X4_GDP, X2_Inflasi, X3_NilaiTukar, X1_SukuBunga
\end{tabular}

a. Predictors: (Constant), X4_GDP, X2_Inflasi, X3_NilaiTukar, X1_SukuBunga

b. Dependent Variable: Y_IndeksSaham

Tabel diatas menunjukkan bahwa nilai Adjusted $R$ Square artinya bahwa kontribusi ke empat variabel bebas tersebut terhadap Indeks Harga Saham disektor Propertihanya sebesar $36,3 \%$ sedangkan $63,7 \%$ dipengaruhi faktor lain diantaranya dapat dipengaruhi dari politik,kebijakan BI tentang loan to value (pemberian Kredit Pemilikan Properti), jumlah uang yang beredar, atau faktor lainnya yang tidak dibahas dalam penelitian ini.

\section{Hasil Uji F}

Tabel Hasil Uji F

ANOVA

\begin{tabular}{rllrrrr}
\hline \multirow{2}{*}{ Model } & & $\begin{array}{c}\text { Sum of } \\
\text { Squares }\end{array}$ & df & Mean Square & F & \multirow{2}{*}{ Sig. } \\
\hline \multirow{2}{*}{1} & Regression & 12427.821 & 4 & 3106.955 & 3.56 & $.033^{\text {b }}$ \\
\multirow{2}{*}{1} & Residual & 12218.883 & 14 & 872.777 & & \\
& Total & 24646.704 & 18 & & & \\
\hline
\end{tabular}

a. Dependent Variable: Y_IndeksSaham

Tabel diatas menunjukkan bahwa nilai $\mathrm{F}$ hitung $=3,560>\mathrm{F}$ table $=3,41$ dan angka signifikansi $=0.033<\alpha=0,05$ sehingga signifikan. Tabel uji $\mathrm{F}$ di atas, menunjukkan bahwa nilai $F_{\text {hitung }}$ sebesar 3,56 dengan tingkat signifikansi sebesar 0,033. Nilai tersebut kurang dari taraf signifikan alpa $=5 \%(0,05)$. Sedangkan untuk mencari $F_{\text {tabel }}$ dengan jumlah sampel $(n)=$ 17 , jumlah variabel $(\mathrm{k})=4$, taraf signifikan $\alpha=0,05$, df1 $=\mathrm{K}-1=4-1=3$ dan df $2=\mathrm{n}-\mathrm{k}=17-4$ $=13$, diperoleh nilai $F_{\text {tabel }}$ sebesar 3,41 sehingga $F_{\text {hitung }}(3,560)>F_{\text {tabel }}(3,41)$. Artinya berdasarkan uji F diatas bahwa secara simultan 7 Day Rate Repo, inflasi, nilai tukar dan PDB berpengaruh signifikan terhadap Indeks Harga Saham sektor Properti.

\section{Hasil Uji T (Secara Parsial)}

\begin{tabular}{|c|c|c|c|c|c|c|}
\hline & & & $\begin{array}{l}\text { Hasil Uj } \\
\text { Coefficien }\end{array}$ & & & \\
\hline Mode & & Unstandard & Coefficients & $\begin{array}{l}\text { Standardized } \\
\text { Coefficients }\end{array}$ & $t$ & Sig. \\
\hline & & B & Std. Error & Beta & & \\
\hline & (Constant) & 850.804 & 339.685 & & 2.505 & 0.025 \\
\hline & $\begin{array}{l}\text { X1_7 Days Rate } \\
\text { Repo }\end{array}$ & -2355.299 & 1045.822 & -0.563 & -2.252 & 0.041 \\
\hline 1 & X2_Inflasi & 22.224 & 19.342 & 0.245 & 1.149 & 0.27 \\
\hline & X3_NilaiTukar & 0.027 & 0.01 & 0.638 & 2.757 & 0.015 \\
\hline & X4_GDP & -92.995 & 52.08 & -0.456 & -1.786 & 0.096 \\
\hline
\end{tabular}

a. Dependent Variable: Y_IndeksSaham

Tabel menunjukan bahwa hasil uji t secara parsial dan untuk penjelasan dari hasil yang diperoleh adalah sebagai berikut:

1. Pengujian pengaruh 7 Day Rate Repo terhadap IndeksHarga Saham sektor Properti (H1) 
Berdasarkan table diatas dapat diketahui bahwa nilai $\mathrm{t}_{\text {hitung }}-2,252<\mathrm{t}_{\text {table }} 2,160$ dengan angka signifikansi $=0,041<\alpha=0,05$ sehingga signifikan (Ho ditolak dan Ha diterima). $\mathrm{T}$ table bisa dihitung pada table t-test, dengan $\alpha=0,05$. Didapat $\mathrm{t}_{\text {tabel }}$ adalah $2,160\left(\mathrm{~T}_{\text {tabel }}=(\alpha: 2 ; \mathrm{n}\right.$ $\mathrm{k}), \mathrm{T}_{\text {tabel }}=(0,05: 2 ; 17-4)$ dan hasilnya $=(0,025 ; 13)$. Dengan demikian hipotesis bahwa 7 Day Rate Repo berpengaruh terhadap Indeks Harga Saham di sektor Properti.Pengaruh negative dapat disebabkan pada periode pengamatan bahwa suku bunga 7 Day Rate Repoyang lebih rendah dibandingkan pada sebelum efektifnya 7 Day Rate Reposehingga banyaknya investor yang beralih investasi di pasar modal khususnya disektor properti. Pada saat suku bunga rendah, maka semakin tinggi minatkredit untuk kepemilikan atas propertisehingga berdampak meningkatnya kinerja perusahaan properti.

2. Pengujian hipotesis pengaruh inflasi terhadap Indeks Harga Saham sektor Properti (H2).

Nilai $\mathrm{t}_{\text {hitung }} 1,149<\mathrm{t}_{\text {table }} 2,160$ dengan angka signifikansi $0,270>\alpha=0,05$ sehingga tidak signifikan (Ho diterima dan menolak Ha). Dengan demikian hipotesis bahwa Inflasi tidak berpengaruh terhadap Indeks Harga Saham sektor Properti

3. Pengujian hipotesis pengaruh nilai tukar terhadap Indeks Harga Saham sektor Properti (H3).

Nilai $t_{\text {hitung }} 2,757>t_{\text {table }} 2,160$ dengan tingkat siginifikan $0,015<\alpha=0,05$ sehingga memilki pengaruh yang signifikan (Ho ditolak dan Ha diterima). Dengan demikian hipotesis H3 bahwa nilai tukar berpengaruh terhadap indeks Harga Saham di sektor Properti.Pengaruh positif dapat disebabkan nilai tukar rupiah yang semakin tinggi terhadap dolar menyebabkan para pengembang terpacu melakukan meningkatkan usahnya disektor properti.Sehingga dapat berdampak pada kinerja perusahaan yang semakin baik, dan investor tertarik untuk berinvestasi saham di sektor properti.

4.Pengujian hipotesis pengaruh PDB terhadap Indeks Harga Saham sektor Properti (H4).

Nilai $\mathrm{t}_{\text {hitung }}-1,786<\mathrm{t}_{\text {table }} 2,160$ dengan angka signifikan $=0,96>\alpha=0,05$ sehingga tidak signifikan (Ho diterima dan Ha ditolak). Dengan demikian hipotesis H4 bahwa PDB tidak berpengaruh terhadap Indeks Harga Saham sektor Properti.Meningkatnya atau menurunnya PDB tidak mempengaruhi investor dalam keputusannya untuk berinvestasi di pasar modal.

\section{KESIMPULAN DAN SARAN}

Hasil pengujian ini menunjukkan dengan nilai $\mathrm{R}$ sebesar $36,3 \%$ yang mengartikan bahwa variabel 7 Day Rate Repo, inflasi, nilai tukar dan PDB hanya mempengruhi 36,3\% terhadap Indeks Harga Saham sektor Properti sehingga 63,4\% dipengaruhi faktor makro lain seperti kebijakan Bank Sentral terhadap loan to value, jumlah uang beredar atau faktor makro lain. Dan dapat juga dipengaruhi faktor internal misalnya laporan kinerja perusahaan. Hasil pengujian menunjukkan secara simultan variabel 7 Day Rate Repo, inflasi, nilai tukar dan PDB berpengaruh secara signifikan terhadap Indeks Harga Saham di sektor Properti. Pengujian dengan regresi berganda menunjukkan variabel 7 Day Rate Repo berpengaruh negatif signifikan terhadap Indeks Harga Saham di sektor Properti. Hal ini dapat mengindikasikan bahwa jika suku bunga rendah membuat konsumen tertarik akan membeli perumahan dengan memanfaatkan fasilitas kredit perbankan. Sehingga menaikkan laporan kinerja pada perusahaan properti yang berimbas pada meningkatnya Indeks Harga Saham di sektor Properti. Nilai tukar menghasilkan pengujian yang positif signifikan sehingga mengartikan bahwa nilai tukar rupiah yang menguat terhadap dollar akan meningkatkan Indeks Harga Saham di sektor Properti juga meningkat. Nilai tukar yang menguat memberikan sinyal positip bagi para konsumen untuk memiliki perumahan. Variabel Inflasi dan Produk Domistik Bruto (PDB) tidak berpengaruh pada Indeks Harga Saham sektor 
Properti pada periode setelah penerapan 7 Day Rate Repo. Adapun saran untuk Penelitian selanjutnya diharapkan dapatmeneliti dengan periode pengamatan yang lebih panjang sejak diberlakukannya 7 Day Rate Repo. Peneliti selanjutnya dapat menambahkan variabel makro lainnya terlihat bahwa nilai koefisien determinasi $\mathrm{R}$ hanya $36,3 \%$ dimana sisanya dipengaruhi faktor makro lainnya, sehingga dapat dilakukan penelitian lebih lanjut untuk dapat melihat variabel-variabel apa saja yang dapat mempengaruhi Indeks Harga Saham sektor Properti. Investor dapat mempertimbangkan faktor-faktor variabel dalam penelitian terhadap Indeks Harga Saham di sektor yang lain atau pada semua sektordi Bursa Efek.

\section{DAFTAR PUSTAKA}

Arif, Dodi. (2014). Pengaruh Produk Domistik Bruto, Jumlah Uang beredar, Inflasi dan BI Rate Terhadap Indeks Harga Saham Gabungan di Indonesia Periode 2007 - 2013. Jurnal Ekonomi Bisnis Volume 19 No. 3, Desember 2014

Atik, Yopi Atul Imrpoh. 2012. Pengaruh Inflasi, Nilai Tukar, dan Tingkat Suku Bunga SBI terhadap Harga Saham Perbankan yang Terdaftar di Bursa Efek Indonesia. Fakultas Ekonomi, Universitas Gunadarma, Jakarta.

Indonesia, B. 2018.Data BI Rate, diakses pada tanggal 9 Pebruari 2018 dari http://www.bi .go.id/id/moneter/bi-rate/data/Default.aspx

Indonesia, B. 2018.Informasi Kurs, diakses pada tanggal 9 Pebruari 2018 dari http://www.bi.go.id/id/moneter/informasi- kurs/ transaksi-bi/Default.aspx

Indonesia, B. 2018.Inflasi, diakses pada tanggal 9 Pebruari 2018 dari http://www.bi.go.id/id/moneter/inflasi/data/D efault.aspx

Indonesia, B. (2016, April 25). BI 7 Day (Reserve) Repo Rate. Dipetik Februari 24, 2017, dari Bank Indonesia: http://www.bi.go.id/id/moneter/bi-7day-RR

Fama, E., dan French, K. "Business Condition and Expected Return on stocks and bonds".Journal of financial Economic, 1998.

Kurniawan, Rivan. 2107. Review Kinerja Sektor Properti Semester 1 2017, diunduhpada tanggal 12 Januari 2018 darihttp://rivankurniawan.com

Kontan, 2017. MI siasati penuruan Suku Bunga Acuan, 24 Agustus, hal 11

Nisfiannoor, M. (2009). Pendekatan Statistika Modern Untuk Ilmu Sosial.Jakarta: Salemba Humanika.

Sangkyun, Park, 1997, "Rationality of negative Stock Price Responses to Strong Economics Activity”Journal Financial Analyst, Sept/Oct 1997.

Santoso, S. (2010).Statistik Nonparametik. Jakarta: PT Elex Media Komputindo.

Selviarindi, Priska. (2011). Analisis Pengaruh Makro Ekonomi Terhadap Harga Saham di Bursa Efek Indonesia. Jurnal Skripsi Universitas Sebelas Maret.

Setianto, Budi. (2016). Prospek Investasi saham Sentul City Tbk. per Laporan Keuangan Q3.Diunduh tanggal 12 Januari 2018, https://books.google.co.id/books

Susanti, Emi. (2017). Pengaruh Suku Bunga BI 7 Days Reserve Repo Rate Dan Tingkat Inflasi Terhadap Indeks Harga Saham Gabungan (IHSG) Pada Bulan April - Desember 2016. Universitas Gadjah Mada Yogyakarta

Suparmoko, M.A, Dr. M. 2006.Ekonomi. Bogor: Quadra

Tandelilin, Eduardus. 2010. Portofolio dan Investasi Teori dan Aplikasi: Edisi Pertama. Yogyakarta: Kanisius.

Thobbary, Achmad. 2009.Analisi Pengaruh, Nilai Tukar, Suku Bunga, Laju Inflasi dan Pertumbuhan GDP Terhadap Indeks Harga Saham Sektor Properti (2000-2008), Jurnal tesis Pasca Sarjana Universitas Diponogoro Semarang

Utami. M.dan Rahayu, M., 2003, "Peranan Profitabilitas, Suku Bunga, Inflasi dan Nilai Tukar Dalam Mempengaruhi Pasar Modal Indonesia Selama Krisis Ekonomi”, Jurnal Ekonomi Manajemen, Vol.5, No.2. 
